\title{
The Effects of Production Offshoring on R\&D and Innovation in the Home Country
}

\author{
Bernhard Dachs and Bernd Ebersberger
}

\begin{abstract}
A strong innovation performance based on R\&D, product development and the implementation of advanced production technologies is key for the long-term competitiveness of European economies. This study investigates the effects of production offshoring on R\&D and innovation activities of the firm in the home country. The analysis is based on a dataset of more than 3000 manufacturing firms from seven European countries. We employ propensity score matching to compare R\&D and innovation activities of firms which have offshored production activities in a previous period to a control group of non-offshoring firms.

The analysis finds no negative effect of production offshoring on innovation and technological capabilities of firms in the home country. On contrary, offshoring firms spend significantly more on R\&D or product design, and invest more in process innovation than non-offshoring firms. These results support a view on internationalisation of firms that regards offshoring as a strategy of international expansion, and not a passive reaction of firms to a loss of their competitiveness. Our results indicate that this expansion goes hand in hand with innovation and process modernization at home.
\end{abstract}

Keywords: offshoring, innovation, R\&D, home country effects, investment

JEL-codes: F230, F610, O310, O330

Die FIW-Studien 2013/14 zeigen die Ergebnisse von den drei Themenbereichen "Trends und Auswirkungen von ausländischen Direktinvestitionen", "Österreichs "Trade in Value Added"'' und "Analyse der österreichischen Warenverkehrsbilanz", die im Rahmen des "Forschungsschwerpunkts Internationale Wirtschaft" (FIW) 2012 vom Bundesministerium für Wirtschaft, Familie und Jugend (BMWFJ) ausgeschrieben und aus Mitteln der Internationalisierungsoffensive finanziert wurden. 



\section{The Effects of Production Offshoring on R\&D and Innovation in the Home Country}

Studie im Rahmen des FIW-Studienpools 2012

Bernhard Dachs, AIT Austrian Institute of Technology, Wien

Bernd Ebersberger, Management Center Innsbruck (MCl), Innsbruck 



\section{Contents}

The Effects of Production Offshoring on R\&D and Innovation in the Home Country........ 1

Studie im Rahmen des FIW-Studienpools 2012 ................................................................................ 1

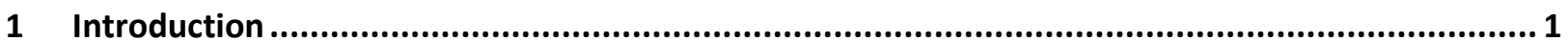

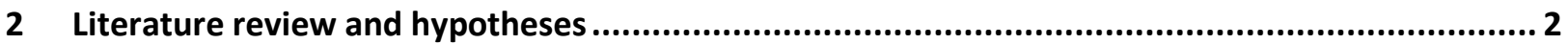

2.1 Offshoring, innovation, and investment in new technologies ................................................. 2

2.2 The home country effects of foreign direct investment and offshoring...................................... 4

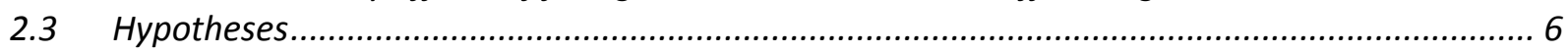

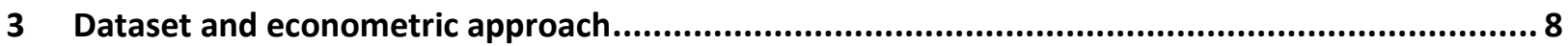

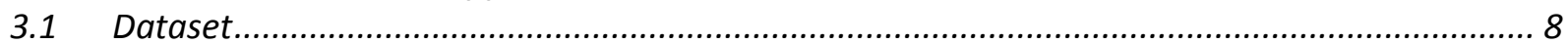

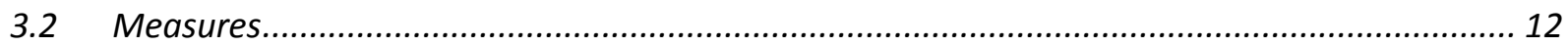

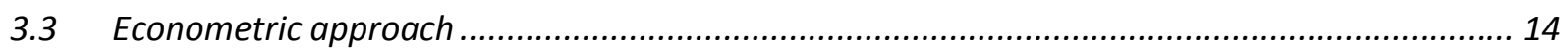

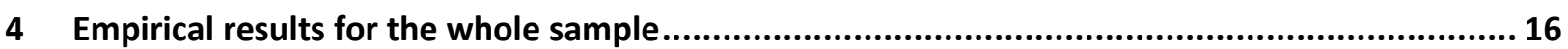

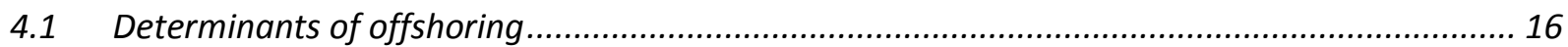

4.2 Offshoring and the firms' production and value chain .......................................................... 18

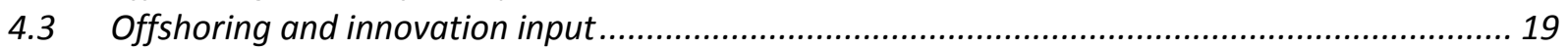

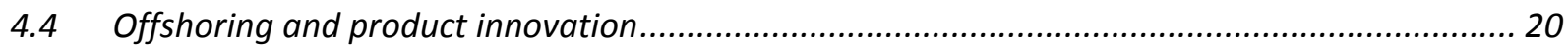

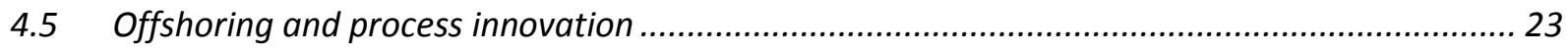

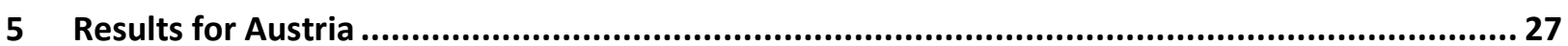

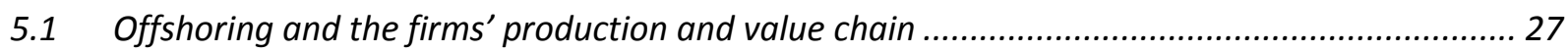

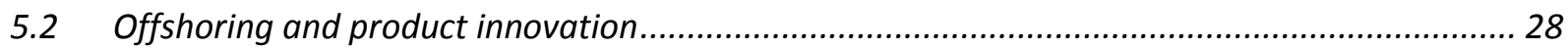

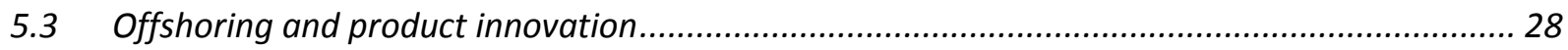

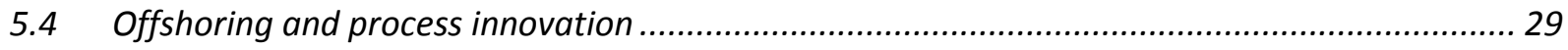

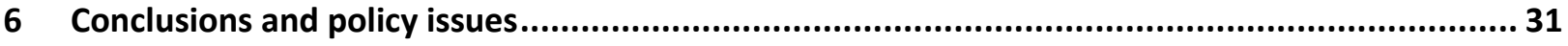

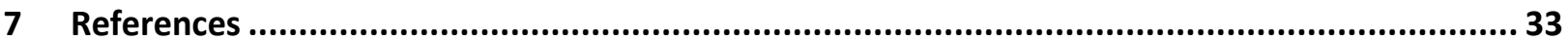

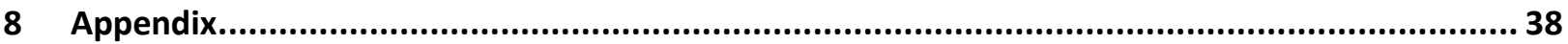




\section{Tables}

Table 2-1 Insourcing, outsourcing and offshoring 2

Table 3-1 Geographical composition of the sample 8

Table 3-2 Sectoral composition of the sample 9

Table 3-3 Operationalization of product innovation output 10

Table 3-4 Description of the technologies 11

Table 3-5 Example computation of an involvement index 12

Table 3-6 Offshoring of production activities between 1999-2006 by sector 13

Table 3-7 Offshoring of production activities between 1999-2006 by country 14

Table 4-1 Determinants of the offshoring decision 17

Table 4-2 Propensity score before and after matching 18

Table 4-3 Effects of offshoring on production activities and the value chain of the firm 19

Table 4-4 Effects of offshoring on innovation input 20

Table 4-5 Effect of offshoring on product innovation 21

Table 4-6 Average process technology involvement by sector 23

Table 4-7 Effect of offshoring on process innovation 25

Table 5-1 Effects of offshoring on production activities and the value chain of Austrian firms 27

Table 5-2 Effects of offshoring on innovation input of Austrian firms 28

Table 5-3 Effects of offshoring on production activities and the value chain of Austrian firms 29

Table 5-4 Effects of offshoring on process innovation of Austrian firms 30

Table 9-1 Share of firms which have introduced a certain process technology 38 


\section{Introduction}

In recent years, firms from different countries have considerably increased their presence abroad. The OECD (2013) estimates that the world-wide stock of foreign direct investment (FDI) has reached around USD 21.1 trillion at the end of 2011. This is a 5\% increase from the value for 2010 , and $27 \%$ increase from 2007 . Increasing FDI activity can also be observed for Austrian firms. Data provided by the Austrian National Bank indicate that active FDI of Austrian firms abroad exceeds the stock of passive FDI of foreign-owned firms in Austria (Dell'mour 2012).

These increases explain why foreign direct investment and offshoring in particular has been in the focus of economic policy debates in the US, Europe and also in Austria for - at least the last decade. A main interest in these debates is on the economic effects of offshoring on the investing firms in the home country. Critics of globalisation blame offshoring for job losses, a weakening of the manufacturing base of European countries and therefore see offshoring as a potential threat to the innovative capabilities of countries and their long-term competitiveness.

This study wants to contribute to this discussion. By investigating the link between offshoring and investments in $R \& D$, innovation and process technology at home, the study will contribute to a better understanding of the effects of outward FDI on the home country. The key question of this project is: How does production offshoring affect innovation capabilities of the firm? This includes, for example, the effects of production offshoring on the propensity to introduce new products, the propensity to introduce new production technologies, or the resources the firm devotes to R\&D. The large literature that investigates such home country effects (Lipsey 2002; Barba Navaretti and Falzoni 2004; Crinò 2009) is however mostly focussed on employment, production and exports. Innovation and technology are usually left outside.

We employ data from the European Manufacturing Survey (EMS) survey, a firm-level data set on product, process, and organisational innovation in manufacturing firms. In order to analyse the causal effect offshoring on the innovation capabilities of firms, we use a propensity score matching estimator. This approach allows us to identify a control group of non-offshoring firms with characteristics similar to those of offshoring firms.

The study is structured as followed: chapter 2 reviews the relevant literature and presents three hypotheses on the relationship between offshoring and innovation capabilities at home. Chapter 3 presents our dataset, some descriptive results and lays out the econometric approach of the study. Empirical results are presented in chapter 4. In chapter 5 we repeat the analysis of chapter 4 with a smaller sample of Austrian firms. Finally, chapter 6 discusses some conclusions from the study. 


\section{Literature review and hypotheses}

This chapter briefly reviews the relevant literature for this study. We will first discuss the concepts of offshoring and innovation. Second, we focus on the empirical literature that examines effects of offshoring and outward foreign direct investment on the home country. Finally, we formulate three hypotheses that will be tested in the empirical analysis of chapter 4.

\subsection{Offshoring, innovation, and investment in new technologies}

The study focusses on the relationship between production offshoring and innovation, with a special focus on process innovation which is investment in new production technologies.

In the context of this study, offshoring is defined as the transfer of production activities to another unit of the firm abroad or a supplier located abroad (see Table 2-1). Offshoring is a type of foreign direct investment of firms ('vertical FDI'), and sometimes used as a synonym for FDI. Related terms are 'international outsourcing', 'international insourcing', the 'fragmentation of global value chains', 'slicing up the value chain', 'global production sharing', or 'trade in tasks' which all describe the location of different stages of the production process at different locations (Stehrer et al. 2012). The most frequent motive for offshoring in European manufacturing are reductions in labour costs, followed by vicinity to customers, and the wish for expansion (Dachs et al. 2012, p. 11).

Table 2-1 Insourcing, outsourcing and offshoring

\begin{tabular}{|c|c|c|}
\hline & National & International \\
\hline Between firms (outsourcing) & $\begin{array}{l}\text { Domestic } \\
\text { outsourcing }\end{array}$ & International outsourcing \\
\hline Within firms (insourcing) & Domestic supply & International insourcing \\
\hline
\end{tabular}

Source: Olsen (2006), p. 7

Innovation is 'the implementation of a new or significantly improved product (good or service), or process, a new marketing method, or a new organisational method in business practices, workplace organisation or external relations. '(OECD 2005, p. 46). A basic distinction can be made between innovation that aims at the introduction of new or considerably improved products to the market (product innovation) and innovation that aims at the introduction of new or considerably improved technologies to produce products (process innovation). 
Innovation in firms can be described as the accumulation of competencies - knowledge and information - in a complex, cumulative, path-dependent process (Dosi 1988; Patel and Pavitt 1997; Pavitt 2005). The process of innovation is highly industry-specific, and therefore differs considerably between sectors. The level of technological opportunity, expectations of future demand and the conditions to appropriate the returns from innovation have been identified as key determinants for the level of innovative activity at the sectoral level (Cohen 1995, 2010).

According to Pavitt (2005, p. 88), firms have to fulfil three principal tasks in the innovation process: a) producing scientific and technological knowledge; b) translating this knowledge into working artefacts; $c$ ) influencing and responding to market demand.

The creation of new scientific and technological knowledge often takes place in designated R\&D departments. But also other departments (such as design, production, or the marketing department) can contribute to the firm's stock of knowledge because they have different experiences with technologies or market demand. Moreover, the firm draws on knowledge from universities, competitors, specialised suppliers and the general knowledge base of society.

The main challenge in transferring knowledge into products is the fact that a new scientific principle does not necessarily lead to a working product. The number of possible design configurations of a product is limited by a number of factors, such as available materials and production technologies, complementary technologies (displays and batteries in the case of mobile phones), or necessary infrastructure (gas stations for hydrogen cars). As a consequence, firms are faced with a fundamental technological uncertainty when developing products. One strategy to master this uncertainty is to broaden the knowledge base to cover many different technologies.

A final principal task in the innovation process is to match the product with changing market demand. This is easier during periods where technological change moves along stable trajectories and basic characteristics of the product develop in a fairly predictable way (Dosi 1982). The task becomes very difficult for the firm when new technologies and competitors rival its main product.

The description of the three tasks of innovation activity makes clear that innovation is not only $R \& D$, but also includes a range of other non-R\&D activities, from the acquisition of external knowledge, to design, testing, the development of prototypes to production preparation and adaptations in the production process (OECD 2005). There are numerous historical examples of how new production technologies can pave the way to product innovation by allowing a greater accuracy, more functionality or reducing production cost. New products, in turn, may require new production technologies for their realisation, and these may be applied in the home market first. Some firms even innovate without any own R\&D activities, mostly based on external knowledge incorporated in machinery or software (Som 2012). The analysis will consider this broad approach to innovation and include 
various indicators that measure product and process innovation. In addition, we will include measures of innovation input, the efforts firms spend on innovation activity.

\subsection{The home country effects of foreign direct investment and offshoring}

Foreign direct investment and offshoring in particular has been in the focus of economic policy debates for - at least - the last decade. The main reasons for this interest are the economic effects of offshoring on the home countries. A vast literature has examined these effects with early contributions going back as far as the 1930s (see the surveys of Lipsey 2002; Barba Navaretti and Falzoni 2004; Olsen 2006; Crinò 2009). Most studies focussed on output, employment or skills and find a complementary relationship between foreign and domestic economic activity, at least in the long run (Lipsey 2002; Barba Navaretti and Falzoni 2004; see Falk and Wolfmayr 2010 for Austria). Overall effects, however, seem relatively small.

The literature has identified several mechanisms how offshoring affects economic activity in the home country (Barba Navaretti and Falzoni 2004, p. 218): first, offshoring may affect output and employment in the home country simply because overseas and home country activities complement or substitute each other. If the firm produces the same product at the offshoring location as in the home country, production in the home country may decline in the short run. If offshoring is also a means to open up new markets abroad, additional demand for the stages of production located at home may counterbalance this decline. This may also include additional demand for headquarter activities such as R\&D, design, and other innovation activities.

Second, offshoring affects home country activities because it changes internal division of labour between various parts of the firm. It will raise the demand for more capital-, technology-, and skills-intensive types of economic activity in the home country, including headquarter services such as supervising, coordinating and other value adding auxiliary activities. As a consequence, the composition of inputs in the home country changes.

Third, activities in the home country may benefit from transfers from the foreign affiliates, most notably reverse technology transfer from overseas R\&D activity (Fors 1997; Ambos and Schlegelmilch 2006; Piscitello and Rabbiosi 2006; D'Agostino et al. 2010). Multinational firms have considerable internationalized their R\&D and innovation activities in recent years. Overseas activities can become a source of competitive advantage for firms and home countries (Narula and Michel 2009), in particular when complementarities between the home region and offshore R\&D exist (D'Agostino et al. 2013).

In the context of this study, the second effect - the changes in the specialisation of economic activities in the home country - seems most relevant. Such a change in specialisation patterns of firms should benefit activities such as research, product development, design, or product-related service activities. This may be fostered by the third 
effect - reverse technology transfer. However, we cannot isolate this third effect since our dataset does not include information on overseas R\&D and innovation activity.

Empirical evidence for changes in specialisation patterns of home country activities are mainly provided by studies that investigated the effects of offshoring on the skill intensity and composition of the labour force of offshoring firms in the home country. Only few studies investigate other indicators (see Olsen 2006), so we will mainly rely on this indirect evidence.

Early studies include Head and Ries (2002) who study Japanese firms in the 1970s and 1980, and Hansson (2005) who investigates Swedish firms in the 1990s. Both studies find that overseas production has a positive and significant impact on domestic skill intensity, which points to a changing specialisation pattern. This effect is more pronounced when offshoring goes to low-income countries. Egger and Egger (2003) investigate changes in skill intensity from offshoring to Eastern Europe for Austria during the 1990s with an industry-level data set. Their results confirm the aforementioned results. Slaughter (2000) in contrast finds no significant effect for US firms in the 1980s and 1990s.

More recent studies include the contributions of Morrison Paul and Yasar (2009) who investigate the effects of offshoring on the skills intensity in Turkish textiles manufacturing, Harrison and McMillan (2010), or Neureiter and Nunnenkamp (2010), who show that highskilled jobs benefit from offshoring in European Firms. Simpson (2012a) confirms this result for the UK. She finds that relocating low-skill activities to low-wage countries has potential positive effects on investment, employment and output in complementary high-skills activities at home. Simpson (2012b) reveals a similar effect for plant exits in low skills industries. The research of Becker et al. (2012) indicates that offshoring in German multinational firms is associated with a significant shift in the structure of jobs characteristics in Germany towards more non-routine and more interactive tasks, and with a shift towards highly-skilled employees.

The study of Crinò (2012) is an exception in the literature, since he also tackles effects of offshoring on R\&D and innovation which are usually not analysed in these studies. Crinò (2012) investigates the effects of imported inputs on skills intensity of firms in Central and Eastern Europe and Central Asia. He finds that importing inputs is associates with a specialization in high-skill intensive activities such as the production of new goods, improvements of product quality and, to a lesser extent, R\&D and technology adoption. The linkage between offshoring and R\&D in the home country is also investigated by Karpaty and Tingvall (2011) for Swedish multinational firms. They find that offshoring has a negative effect on R\&D intensity of Swedish firms at home. The effect is most robust for offshoring to other European countries and North America. Offshoring to emerging economies, however, has no or even a positive effect on R\&D intensity. The negative effect of offshoring on R\&D intensity can be traced back to small firms. 
The link between offshoring on the one side and R\&D, innovation and investment in process innovation at home on the other side may also be influenced by self-selection. Theoretical as well as empirical research has argued that firm heterogeneity leads to a selection-bias in the internationalisation strategies of firms (Head and Ries 2003; Helpman et al. 2004). Only the most productive firms expand their operations via FDI, while less productive firms choose to export or serve only domestic markets. Recent empirical evidence for differences in productivity between offshoring and non-offshoring firms is provided by Amiti and Wei (2009), Fariñas and Martín-Marcos (2010), or Jabbour (2010). We will account for this bias by employing an econometric matching estimator described below.

As discussed in the previous section, an important part of innovation activity is the introduction of advanced production technologies, or process innovation. A few empirical studies investigate the effects of offshoring FDI on investment in the home country. The results of these studies are inconclusive. Desai et al. (2009) report a positive relationship and indicate that 10 percent increase in FDI is associated with 2.6 percent higher domestic investment at the aggregate level over the period 1982-2004 for the US. Feldstein (1994) in contrast, finds a negative relationship for the US, while Braunerhjelm and Oxelheim (2000) find no general tendency that foreign investment would replace or augment domestic investment of Swedish multinationals. Egger and Pfaffermayr (2009) investigate the effect of FDI on tangible and intangible investments in Austria. They find that investing abroad is positively correlated to higher investments in R\&D and intangible assets at home.

Moreover, firms may concentrate advanced production technologies at home because of the close linkage between improvements in production technology and product innovation (Ketokivi and Ali-Yrkkö 2009; Tecu 2011). The interactive model of the innovation process (Kline and Rosenberg 1986; Rothwell 1992) or the Open Innovation model (Chesbrough 2003) suggest that feedback loops between production activities, product development, and R\&D are a main source of new ideas. These links may be most beneficial with the most advanced production equipment employed and concentrated at the domestic location. Another reason why firms that invest in advanced production technologies may locate these investments in the home country is control. Involuntary spillovers to competitors may be easier to control if machinery is located close to the head office of the firm.

\subsection{Hypotheses}

From the literature, we conclude that offshoring is a process where capital- and skillintensive stages are concentrated at home, while labour-intensive stages of production are located in (low-wage) countries. Moreover, offshoring firms develop a higher demand for headquarter services, including R\&D, design, and other innovation activities. Self-selection and positive feedbacks between process and product innovation may even reinforce this shift. We therefore state an "optimistic" hypothesis to be tested below:

H1: Production offshoring is associated with a higher innovation input of the firm. 
We now turn to product innovation. A higher rate of product innovation seems to be a logic conclusion from $\mathrm{H} 1$; however, successful innovation need market acceptance, which is not related to innovation input. Offshoring firms may nevertheless be more successful with product innovation, because they have a more direct access to foreign markets, and can learn from success and failures with product innovation in other markets. Higher overall sales of the firm from international operations and growth expectations might result in a higher demand for R\&D and innovation located in the home country. Being a multinational firm also enhances the range of possible markets for an innovation (Rosenberg 1990). Moreover, there is empirical evidence that multinational firms have better management capabilities than purely domestically firms (Bloom and Van Reenen 2010). We therefore state $\mathrm{H} 2$ :

H2: Production offshoring is associated with a higher rate of product innovation of the firm.

Finally, we look at process innovation. On the one hand, economic theory predicts that units in the home country will specialize on more skill-intensive and capital-intensive activities, while foreign affiliates typically located in low-wage countries exploit factor price advantages of their host countries in labour-intensive production activities. This also includes process technologies such as highly automated production or flexible, 'customized' manufacturing. Moreover, offshoring may increase the demand for efficient and transparent communication and integration between activities in the home country and foreign manufacturing plants. This may trigger initial or follow-up investment in electronic network technologies such as enterprise resource planning, supply chain management systems or warehouse management systems. Close linkages between production and innovation may further foster a concentration of modern process technologies in the home country.

Process innovation in the home country, however, may also suffer from offshoring for two reasons. First, if offshoring leads to a reduction of production activity in the home country, there may also be less investment in new process technologies. Second, process innovation in the home country may suffer from offshoring if capital-intensive production processes in the home country are substituted by labour-intensive production abroad. Unfortunately, the data does not allow us to distinguish between offshoring to low-wage and to high-wage locations. We nevertheless assume a positive relationship between offshoring and process innovation as well:

H3: Production offshoring is associated with a more process innovation of the firm. 


\section{Dataset and econometric approach}

\subsection{Dataset}

The data employed in the study comes from the European Manufacturing Survey (EMS) ${ }^{1}$. The EMS investigates product, process, service and organisational innovation in European manufacturing. EMS is organized by a consortium of research institutes and universities coordinated by the Fraunhofer Institute for Systems and Innovation Research (ISI). The survey is carried out every three years. Despite the regular intervals, EMS is not a panel survey. First and foremost each survey wave represents a cross section in its own right. Furthermore the questionnaire changes over time, which limits comparisons between different observation periods.

This study will exploit data from the EMS 2009, which includes 3,106 observations from seven countries. German firms have the largest share in the dataset. The most frequent sectors are producers of finished metal products and machinery. Table 3-1 and 3-2 illustrate the geographical and sectoral composition of the sample.

Table 3-1 Geographical composition of the sample

\begin{tabular}{lll}
\hline Country & $\begin{array}{l}\text { Number of } \\
\text { observations }\end{array}$ & Share \\
\hline Germany & 1,482 & $45.3 \%$ \\
Austria & 306 & $9.4 \%$ \\
Switzerland & 678 & $20.7 \%$ \\
Netherlands & 322 & $9.8 \%$ \\
Finland & 131 & $4.0 \%$ \\
Spain & 116 & $3.5 \%$ \\
Slovenia & 71 & $2.2 \%$ \\
\hline Total & 3,106 & $100.0 \%$ \\
\hline
\end{tabular}

Source: EMS

To our knowledge, EMS is the only data source that allows studying the effects of offshoring on R\&D, innovation and production technologies in firms in detail. Other popular data sources, such as the AMADEUS data base, or the FDI intelligence database do only provide a fraction of the variables needed for this analysis. The EMS includes detailed information on the degree of utilization of a number of advanced production technologies, on innovation input including R\&D expenditure, innovation output such as the introduction of new products to the market, the qualification structure of the employees, and a number of

\footnotetext{
${ }^{1}$ http://www.isi.fhg.de/i/projekte/survey_pi.htm
} 
control variables such firm size, as exports, position of the firm in the value chain, or characteristics of the main product and of the production process.

\section{Table 3-2 Sectoral composition of the sample}

\begin{tabular}{llll}
\hline NACE & & $\begin{array}{l}\text { Number of } \\
\text { observations }\end{array}$ & Share \\
\hline Rev. 1.1 & Sector & 256 & $8.24 \%$ \\
\hline $15-16$ & Man. of food products and beverages, tobacco & 88 & $2.83 \%$ \\
$17-19$ & Man. of textiles, clothing and leather & 105 & $3.38 \%$ \\
20 & Man. of wood and of products of wood etc. & 63 & $2.03 \%$ \\
21 & Man. of pulp, paper and paper products & 118 & $3.80 \%$ \\
22 & Publishing, printing and reproduction of recorded media & 166 & $5.34 \%$ \\
$23-24$ & Man. of coke, petroleum products, chemicals and chemical products \\
25 & Man. of rubber and plastic products & 242 & $7.79 \%$ \\
26 & Man. of other non-metallic mineral products & 158 & $5.09 \%$ \\
27 & Man. of basic metals & 89 & $2.87 \%$ \\
28 & Man. of fabricated metal products (excluding machinery) & 572 & $18.42 \%$ \\
29 & Man. of machinery and equipment n.e.c. & 543 & $17.48 \%$ \\
$30-31$ & Man. of office equipment, electrical machinery and apparatus & 142 & $4.57 \%$ \\
32 & Man. of radio, television and com. equipment and apparatus & 98 & $3.16 \%$ \\
33 & Man. of medical, precision and optical equipment & 220 & $7.08 \%$ \\
$34-35$ & Man. of motor vehicles and other transport equipment & 92 & $2.96 \%$ \\
36 & Man. of furniture; manufacturing n.e.c. & 154 & $4.96 \%$ \\
\hline & Total & 3,106 & $100.0 \%$ \\
\hline $50 u(e)$ & &
\end{tabular}

Source: EMS

The three hypotheses of section 2.3 relate offshoring to innovation input, product innovation and process innovation in the home country. The main input into research, development and innovation activities of firms is personnel employed in these areas (e.g. Muscio 2006; Fritsch and Slavtchev 2010). In order to capture the innovation input we take a somewhat broader view on innovation which includes R\&D, but also non-R\&D activities such as design, product adaptation etc. We measure innovation input by the share of personnel of the firm employed in R\&D and the share of personnel employed in configuration, design and R\&D.

The operationalization of product innovation in the EMS survey follows the suggestions laid out in the OECD's Oslo manual (OECD 2005). Product innovation output is captured by a dichotomous variable indicating that the respondent firm introduced a new product to the market in the three year period subsequent to the period covered by the offshoring of production activities between 1999 and 2006. In addition, product innovation output is also 
captured by its economic relevance measured by the share of turnover generated by the new products in the year 2008. In accordance with the OECD (2005) the operationalization of the product innovation output distinguishes between two degrees of novelty: products that are new to the firm and products that are new to the market.

Dichotomous indicators for product innovation have been used for instance by Ebersberger and Herstad (2011), by Nieto and Santamaria (2007), and by Laursen, Masciarelli, and Prencipe (2012). The economic relevance of product innovation measured by the sales share generated by new products has, for instance, been used by Cassiman and Veugelers (2006), by Laursen and Salter (2006), and by Schmiedeberg (2008).

Overall this generates four variables capturing product innovation output. Table 3-3 summarizes the operationalization and provides immediate reference to the tables reporting the corresponding analysis.

Table 3-3 Operationalization of product innovation output

\begin{tabular}{lcc}
\hline & Introduction of new products & Economic relevance of new products \\
\hline New to the firm & Dichotomous variable & Share on turnover \\
New to the market & Dichotomous variable & Share on turnover \\
\hline
\end{tabular}

Source: EMS

A unique feature of the EMS dataset is the richness of information on process innovation. Unlike the Community Innovation Survey (CIS), which only indicates if a firm has introduced a process innovation or not, EMS gives very detailed information on the implementation of 13 different production technologies including the first year of installation. A complete list of the technologies is given in the table below.

The EMS also asked firms for the main motive for the adaptation of a technology. The results of this question not reported here indicate that the main motive for the adaptation of most technologies is to increase productivity. Exceptions are novel materials, biotechnology, prototyping and virtual reality and simulation, which are mainly introduced with the motive of increasing innovation capacities. Moreover, laser and automated quality control are mainly employed to increase the quality of the output. 


\begin{tabular}{|c|c|}
\hline Description of the technology & Abbreviation \\
\hline \multicolumn{2}{|l|}{ Automation technologies } \\
\hline Seamless integration of digital product design/ engineering with machine programming (CAD/CAM) & CAD \\
\hline Industrial robots/handling systems in manufacturing and assembly & ROB \\
\hline (Process)integrated quality control (e.g. by laser, ultrason ic waves,machine vision systems) & QUC \\
\hline Radio Frequency Identification (RFID)- utilization in on-site/external logistics & RFID \\
\hline Automated Warehouse Management Systems (WHS) for on-site logistics and order-picking & WHS \\
\hline \multicolumn{2}{|l|}{ Production technologies } \\
\hline Laser as a tool (e.g. cutting, welding, forming, micro-structuring) & LAS \\
\hline Dry processing/minimum quantity lubrication system & DRY \\
\hline Rapid Prototyping or tooling (e. g. laser sintering, stereo lithography, 3D printing processes) & RAP \\
\hline Application of bio- and gene-technology in manufacturing processes (e.g. catalysts, bio reactors) & GEN \\
\hline Processing of novel materials (e.g. composite materials, renewable raw materials) & MAT \\
\hline \multicolumn{2}{|l|}{ Digital factory technologies } \\
\hline Digital exchange of operation data with supply chain management systems of suppliers/customers & SCM \\
\hline Manufacturing Execution System (MES) (i.e. integration of PPS/ERP with production data, CAM) & MES \\
\hline Virtual Reality and/or simulation in product development and/or manufacturing & VIR \\
\hline
\end{tabular}

Source: EMS

To measure process innovation we generate an indicator that captures the involvement of the firm in these 13 production technologies on a detailed basis. Stronger involvement indicated by a higher involvement index reveals more intensive process innovation as more of these advanced production technologies have been implemented to achieve a higher level of technology involvement.

We construct an additive involvement index that resembles the index used in Ebersberger and Herstad (2012), in Bozeman and Gaughan (2007, 2011) and in Gaughan and Corley (2010). It is constructed by first identifying the technologies that a firm currently utilizes. Each of these instances of technology usage is then weighted with the inverse of their relative frequency in the respective NACE 2-digit industry group, and the sum is computed. This procedure weights up (relatively) rare utilization of technologies, and weight down (relatively) common ones. We compute a total involvement index (all technologies) and separate indexes for involvement in automation technologies, production technologies and in digital factory technologies. The relative frequency of technology utilization in the sectors in the data set is reported in Table 9-1 in the Appendix. 
As an example, consider a firm initially utilizing only in other CAD/CAM technologies (a automation technology) and virtual reality / simulation in product development (a digital factory technology). In the NACE 2-digit sector of this very firm, CAD/CAM usage is common as $53 \%$ of the firms employ CAD/CAM systems. Virtual reality / simulation in product development is relatively rare as $14 \%$ in the sector employ this technology. The computation of the involvement index of this firm is reported as an illustration in Table 3-5.

Table 3-5 Example computation of an involvement index

\begin{tabular}{ll}
\hline For employing CAD/CAM & $1^{*}(1-0.53)+$ \\
For employing virtual reality & $1^{*}(1-0.14)+$ \\
For all other not employed technologies & $0^{*}(1-\ldots)$ \\
\hline Involvement index & 1.33 \\
\hline Source: EMS &
\end{tabular}

Finally, offshoring is operationalized in the EMS by a question which asks if the firm has moved production activities to own or foreign firms abroad during a certain period of time. In the case of EMS 2009, this period of time is between 1999 and 2006. This allows estimating a causal relationship between production offshoring between 1999 and 2006, and innovation input, product and process innovation in the period 2007-2009.

\subsection{Measures}

Table 3-1 and Table 3-2 provide some descriptive statistics on the sample distribution across sectors and countries.

In a sectoral perspective, the highest share of offshoring firms can be found in textiles, clothing and leather and among the manufacturers of office equipment, electrical machinery and apparatus. Production processes and the propensities of the final product in these sectors allow a high degree of division of labour between various stages of production and therefore a high degree of offshoring.

The data reveal that $13.6 \%$ of the total sample have offshored production to own or foreign firms between 1999 and 2006. Offshoring firms are surprisingly equally distributed between the countries. The relative shares range between $10.2 \%$ in the Netherlands and $16.3 \%$ in Austria. Empirical evidence for offshoring in the period 2007-2009 is provided by Dachs et al. (2012). 
Table 3-6 Offshoring of production activities between 1999-2006 by sector

\begin{tabular}{lrrrr}
\hline Sector & $\begin{array}{c}\text { No } \\
\text { offshoring }\end{array}$ & Offshoring & $\begin{array}{r}\text { Share on } \\
\text { total }\end{array}$ & Total \\
\hline Man. of food products and beverages, tobacco & 246 & 10 & $3.9 \%$ & 256 \\
Man. of textiles, clothing and leather & 58 & 30 & $34.1 \%$ & 88 \\
Man. of wood and of products of wood etc. & 100 & 5 & $4.8 \%$ & 105 \\
Man. of pulp, paper and paper products & 54 & 9 & $14.3 \%$ & 63 \\
Publishing, printing and reproduction of recorded media & 115 & 3 & $2.5 \%$ & 118 \\
Man. of coke, petroleum, chemicals and chemical products & 145 & 21 & $12.7 \%$ & 166 \\
Man. of rubber and plastic products & 216 & 26 & $10.7 \%$ & 242 \\
Man. of other non-metallic mineral products & 151 & 7 & $4.4 \%$ & 158 \\
Man. of basic metals & 75 & 14 & $15.7 \%$ & 89 \\
Man. of fabricated metal products (excluding machinery) & 528 & 44 & $7.7 \%$ & 572 \\
Man. of machinery and equipment n.e.c. & 450 & 93 & $17.1 \%$ & 543 \\
Man. of office equipment, electrical machinery and & 91 & 51 & $35.9 \%$ & 142 \\
apparatus & & & & \\
Man. of radio, television and communication equipment & 73 & 25 & $25.5 \%$ & 98 \\
and apparatus & & & & \\
Man. of medical, precision and optical equipment & 185 & 35 & $15.9 \%$ & 220 \\
Man. of motor vehicles and other transport equipment & 66 & 26 & $28.3 \%$ & 92 \\
Man. of furniture; manufacturing n.e.c. & 131 & 23 & $14.9 \%$ & 154 \\
\hline Total & & & & \\
\hline Source & 2,684 & 422 & $13.6 \%$ & 3,106 \\
\hline
\end{tabular}

Source: EMS 
Table 3-7 Offshoring of production activities between 1999-2006 by country

\begin{tabular}{lrrrr}
\hline Country & No offshoring & Offshoring & Share on total & Total \\
\hline Germany & 1,282 & 200 & $13.5 \%$ & 1,482 \\
Austria & 256 & 50 & $16.3 \%$ & 306 \\
Switzerland & 583 & 95 & $14.0 \%$ & 678 \\
Netherlands & 289 & 33 & $10.2 \%$ & 322 \\
Finland & 113 & 18 & $13.7 \%$ & 131 \\
Spain & 100 & 16 & $13.8 \%$ & 116 \\
Slovenia & 61 & 10 & $14.1 \%$ & 71 \\
& & & & \\
\hline Total & 2,684 & 422 & $13.6 \%$ & 3,106 \\
\hline
\end{tabular}

Source: EMS

\subsection{Econometric approach}

The econometric analysis will proceed in two steps. First, we model the offshoring decision. We assume that the firms' decision whether or not to offshore production activities is related to firm-specific characteristics $X$. The influence of these firm level characteristics is estimated with a probit model, where the offshoring decision OFFS is the dependent variable:

$$
\mathrm{P}\left(\mathrm{OFFS}_{i}=1\right)=\Phi\left(X_{i}\right)
$$

$\Phi$ is the cumulative normal density function. $X$ contains firm specific characteristics such as size, age, experience with various production technologies, sector and country.

Second we use the estimated propensity of the first step for a propensity score matching to construct the counterfactual for the offshoring (for the methodology see for example Heckman et al. 1998; Blundell and Costa Dias 2000; Czarnitzki 2005). This allows us to control for the selection bias and estimate the offshoring effect on the investment in R\&D, on the implementation of advanced production technologies and on innovation activities.

The temporal structure of the dataset also allows us to address potential endogeneity. Offshoring of production activities between 1999 and 2006 will be modelled using information about the firm characteristics in the year 1999. The information to assess the effects of this offshoring between 1999 and 2006 relate to the years 2007 to 2009 . 
The effect of offshoring is the difference between the innovation behaviour $I_{T}$ of offshoring firms ( $O F F S=1)$ and the innovation behaviour of the offshoring firms in the unobserved case where they had not offshored $I_{C}$.

$$
E(\theta)=E\left(I_{T} \mid O F F S=1\right)-E\left(I_{C} \mid O F F S=1\right)
$$

As the second part of (2) cannot be observed, $E\left(I_{C} \mid O F F S=1\right)$ has to be estimated. Matching methods solve this missing data problem by estimating the counterfactual. For each of the offshoring firms the matching approximates the counterfactual behaviour through the behaviour of a non-offshoring firm that is similar to the offshoring firm in terms of exogenous characteristics $X$. The effect of offshoring is

$$
E(\theta)=E\left(I_{T} \mid O F F S=1, X=x\right)-E\left(I_{C} \mid O F F S=0, X=x\right)
$$

As a matching procedure we use the kernel based matching approach. It constructs a convex combination of all not-offshoring firms to be each offshoring firm. The higher the similarity of the non-offshoring firm to the offshoring firm in the characteristics space $(X)$ the higher its weight is in the convex combination. We use a Gaussian kernel with a bandwidth of 0.034 . The composition of the conditional sample is such that between the group of offshoring firms and the group of not-offshoring firms no systematic differences exist which influence the offshoring decision. Rosenbaum and Rubin (1983) show that using the propensity score is an appropriate way to solve the problem of finding identical pairs in all dimensions of $X$. The probit model in (1) does not only supply evidence to analyse the determinants of offshoring. It also supplies the propensity score for the matching analysis. 


\section{Empirical results for the whole sample}

\subsection{Determinants of offshoring}

In this first step of the empirical analysis we investigate the determinants of production offshoring. The offshoring of production activities is captured by a dichotomous variable indicating that production activities have been offshored in the years 1999 to 2006 . The independent variables in the subsequent regressions are measured for the year 1999. The subsequent regressions include a summary indicator for the use of modern organizational concepts in management in the year $1999\left(\mathrm{ORG}_{99}\right)$. It also contains the 1999 usage of eleven different production technologies (Use_xx $x_{99}$ ). Additionally we include country dummies, sector dummies, firm age dummies and two size indicators which control for the broad size class of the firm (small, medium, large firm) in the period 2007-2009. The affiliation of each firm to these size classes should be fairly stable between 1999 and 2009 .

The regression that supplies the propensity score for the subsequent matching analysis also includes interaction terms for country and sector. The results for some base line regressions (Model I to Model III) are reported in Table 4-1. The regression used for the propensity score is reported in Table 4-1 in Model IV. 


\begin{tabular}{|c|c|c|c|c|c|c|c|c|}
\hline & \multicolumn{8}{|c|}{ Dependent Variable: Offshoring of production activities in 1999 - 2006} \\
\hline & \multicolumn{2}{|l|}{ Model I } & \multicolumn{2}{|l|}{ Model II } & \multicolumn{2}{|l|}{ Model III } & \multicolumn{2}{|l|}{ Model IV } \\
\hline & $\mathrm{b}$ & se & $\mathrm{b}$ & se & $\mathrm{b}$ & se & $\mathrm{b}$ & se \\
\hline $\mathrm{ORG}_{99}$ & & & & & $0.385^{\star}$ & 0.189 & 0.529 & 0.317 \\
\hline Use_CAD 99 & 0.152 & 0.090 & 0.061 & 0.094 & 0.032 & 0.095 & 0.030 & 0.101 \\
\hline Use_ROB 99 & $0.348^{\star * *}$ & 0.090 & $0.334^{* * *}$ & 0.093 & $0.299^{* *}$ & 0.095 & $0.211^{*}$ & 0.101 \\
\hline Use_QUC 99 & 0.048 & 0.105 & 0.06 & 0.108 & 0.020 & 0.11 & -0.048 & 0.116 \\
\hline Use_RFID 99 & 0.297 & 0.343 & 0.361 & 0.363 & 0.364 & 0.36 & 0.412 & 0.380 \\
\hline Use_WHS 99 & $0.325^{\star \star}$ & 0.115 & $0.291^{*}$ & 0.118 & $0.257^{*}$ & 0.12 & 0.133 & 0.127 \\
\hline Use_LAS 99 & $0.350^{\star *}$ & 0.112 & $0.340^{* *}$ & 0.116 & $0.315^{\star \star}$ & 0.117 & $0.325^{\star *}$ & 0.121 \\
\hline Use_DRY $_{99}$ & 0.015 & 0.126 & 0.075 & 0.131 & 0.057 & 0.131 & -0.02 & 0.137 \\
\hline Use_RAP99 & $0.583^{\star \star}$ & 0.203 & $0.569^{* *}$ & 0.208 & $0.540^{\star \star}$ & 0.209 & $0.539^{*}$ & 0.223 \\
\hline Use_MAT99 & -0.463 & 0.498 & -0.364 & 0.531 & -0.360 & 0.526 & -0.467 & 0.553 \\
\hline Use_SCM9g & -0.025 & 0.128 & -0.037 & 0.133 & -0.058 & 0.133 & -0.058 & 0.143 \\
\hline Size (small) & & & & & & & $0.289^{* * *}$ & 0.087 \\
\hline Size (large) & & & & & & & $-0.244^{\star \star *}$ & 0.065 \\
\hline Country $^{+}$ & No & & Yes & & Yes & & Yes & \\
\hline Sector ${ }^{+}$ & No & & Yes & & Yes & & Yes & \\
\hline $\mathrm{Age}^{+}$ & No & & No & & No & & Yes & \\
\hline Country $^{+*}$ sector & No & & No & & No & & Yes & \\
\hline$N$ & 3106 & & 3106 & & 3106 & & 3011 & \\
\hline Log likelihood & -1492.24 & & -1410.75 & & -1408.69 & & -1314.21 & \\
\hline R2 & 0.027 & & 0.08 & & 0.081 & & 0.130 & \\
\hline Chi2 & $81.3^{* * *}$ & & $244.3^{\star \star *}$ & & $248.5^{\star \star \star}$ & & $392.8^{* * *}$ & \\
\hline
\end{tabular}

\footnotetext{
Note: + indicates a set of dummy variables. ${ }^{* * *},\left({ }^{* *}, *\right)$ indicates significance at the $1 \%,(5 \%, 10 \%)$ level of significance.
}

To generate the counterfactual for the offshoring firms we use the matching algorithm introduced above. There we argued that the group of non-offshoring enterprises does not represent an unbiased approximation for the counterfactual situation. We argued that there are certain firm specific characteristics that affect the offshoring decision. These characteristics are summarized by the propensity score derived from the probit regression IV in Table 4-1. 


\begin{tabular}{clllll}
\hline & Obs & Mean & Std. Err. & P \\
\hline Propensity score Offshoring (TG) & 412 & $-0.468^{* * *}$ & 0.028 & 0.000 \\
(before matching) & No Offshoring (CG) & 2,590 & -1.026 & 0.010 & \\
\hline Propensity score Offshoring (TG) & 358 & -0.640 & 0.024 & 0.800 \\
(before matching) No Offshoring (CG) & 358 & -0.639 & 0.024 & \\
\hline
\end{tabular}

Note: The group labelled as ,no offshoring' are all the companies in the sample that have not offshored production activities in the years 1999-2006. The propensity score is generated from regression IV in Table 4-1. ${ }^{* * *},\left({ }^{* *}, *\right)$ indicates significance at the $1 \%,(5 \%, 10 \%)$ level of significance.

Before we start with the interpretation of the effects of offshoring on the innovation input, product innovation and on process innovation, let us investigate two related issues. First, let us briefly analyse whether the matching algorithm was able to balance the propensity score of the offshoring firms with the propensity score of the control group. Table 4-2 illustrates that the matching algorithm has succeeded in balancing the sample with respect to the propensity score. We do not find significant differences between the offshoring firms and the matched control group that we use to approximate the counterfactual here.

Second, let us investigate whether the offshoring indicator plausibly captures the increased embeddedness of the firm in international value chains. In order to do so we provide an analysis of the effects of offshoring on the firms' production and their international value chain involvement in Section 4.2. This is not to sketch out the effect --- which would be all too obvious --- but to increase the legitimacy of our indicator.

\subsection{Offshoring and the firms' production and value chain}

The analysis here focuses on the effects of offshoring of production activities which we capture by a dummy variable. This dichotomous variable bases on the self-reported information in the survey about whether or not the respondent firm has offshored production activities in the years 1999-2006. All other things equal, we would expect the offshoring firms to reveal a reduced intensity of production activities. The first two rows of Table 4-3 show that offshoring firms indeed have a significantly $(p=0.000)$ lower share of employees in production (55.8\%) than non-offshoring firms (62.2\%). This confirms one of the central assumptions of this paper: offshoring results in a shift in the internal division of labour of the firm from production to headquarter functions.

In the same manner, we expect that offshoring activities increase the integration of firms in international value chains. In Table 4-3 the integration in international value chains is captured upstream by the fraction of intermediate goods that are imported and downstream by the share of exports on turnover. For both indicators we find that offshoring firms exhibit a significantly ( $p=0.000$ in both cases) more intensive integration than non-offshoring firms. 
In addition to the finding that offshoring firms are more intensively embedded in international value chains we investigate whether this leads to effects, possibly adverse effects, on the firms' delivery time. We observe that the offshoring firms have a mean delivery time of 45.2 days. The matched controls exhibit a delivery time of 47.7 days, which is decisively longer (see Table 4-3, last two rows). Yet, the difference is not significant. Overall, the findings do not indicate a negative effect of offshoring production on the delivery time.

Table 4-3 Effects of offshoring on production activities and the value chain of the firm

\begin{tabular}{|c|c|c|c|c|c|}
\hline & & Obs & Mean & Std. Err. & $\mathrm{Pr}$ \\
\hline \multirow{2}{*}{$\begin{array}{r}\text { Share of employees in } \\
\text { production }\end{array}$} & Offshoring (TG) & 332 & $55.765^{\star \star \star}$ & 1.135 & 0.000 \\
\hline & No Offshoring (CG) & 332 & 62.200 & 0.631 & \\
\hline \multirow{2}{*}{$\begin{array}{r}\text { Share of imported } \\
\text { intermediates }\end{array}$} & Offshoring (TG) & 318 & $45.903^{\star * *}$ & 1.600 & 0.000 \\
\hline & No Offshoring (CG) & 315 & 31.491 & 1.003 & \\
\hline \multirow{2}{*}{$\begin{array}{r}\text { Share of exports on } \\
\text { turnover }\end{array}$} & Offshoring (TG) & 328 & $52.664^{\star * *}$ & 1.777 & 0.000 \\
\hline & No Offshoring (CG) & 328 & 41.800 & 1.227 & \\
\hline \multirow{2}{*}{ Delivery time } & Offshoring (TG) & 325 & 45.246 & 3.783 & 0.559 \\
\hline & No Offshoring (CG) & 325 & 47.660 & 2.734 & \\
\hline
\end{tabular}

Note: The group labelled as ,no offshoring' is all the companies in the sample that have not offshored production activities in the years 1999-2006. The propensity score is generated from regression IV in Table 4-1. ${ }^{* * *},\left({ }^{* *},{ }^{*}\right)$ indicates significance at the $1 \%,(5 \%, 10 \%)$ level of significance.

The findings from Table 4-3 add to the plausibility of the offshoring indicator, on which the analyses of the following sections will base. Moreover, they can also provide us with some insights how the results of this study have been effected by the global financial crisis, which has reached its climax during the observation period 2007-Mid 2009. Empirical evidence suggests that export-oriented firms were more severely hit by the crisis and exhibited more severe cuts in innovation and R\&D expenditure than less export-oriented firms (Paunov 2012; Rammer 2012; Archibugi et al. 2013). Thus, we can assume that the crisis has narrowed down the differences between offshoring and non-offshoring firms observed in the following chapters.

\subsection{Offshoring and innovation input}

Hypothesis 1 stated that offshoring is positively related to innovation input. We investigate this assumption in the following section. We look at differences in R\&D, but also in nonR\&D activities such as design, product configuration and adaptation. In what follows both dimensions - R\&D employees and designers - are captured by their share on total staff of the firm. 
Table 4-4 provides the result of the analyses comparing the offshoring firms with the matched not-offshoring firms which are regarded as the counterfactual to the offshoring firms. For all three indicators - the share of $R \& D$ employees $(p=0.099)$, the share of designers $(p=0.037)$, and the combined share of R\&D employees and designers $(p=0.011)$ - we identify a significant difference between offshoring firms and the control group of nonoffshoring firms.

Comparing the effect of offshoring on R\&D employees with the effect of offshoring on designers we find that the difference in R\&D employees (0.679) is distinctively smaller than the difference in the share of designers (1.116). This may be explained by the fact that multinational firms have a higher need for product adaptations to meet regulations, consumer tastes, environmental conditions etc. in foreign markets compared to national firms. Comparing the relative effect, we find that offshoring in 1999-2006 is associated with an increase in R\&D employees by $13.2 \%$ and with an increase of designers by $16.6 \%$.

Based on these results, we can reject the null-hypothesis claiming no effect of offshoring on innovation input and find support for Hypothesis 1 above.

Table 4-4 Effects of offshoring on innovation input

\begin{tabular}{rllll}
\hline & Obs & Mean & Std. Err. & Pr \\
\hline Share of personnel in Offshoring (TG) & 326 & $13.668^{* *}$ & 0.671 & 0.011 \\
R\&D and design No Offshoring (CG) & 326 & 11.875 & 0.380 & \\
\hline Share of personnel in Offshoring (TG) & 326 & $5.831^{*}$ & 0.376 & 0.099 \\
R\&D No Offshoring (CG) & 326 & 5.152 & 0.227 & \\
\hline Share of personnel in Offshoring (TG) & 326 & $7.837^{* *}$ & 0.514 & 0.037 \\
design No Offshoring (CG) & 326 & 6.721 & 0.265 & \\
\hline
\end{tabular}

Note: The group labelled as ,no offshoring' are all the companies in the sample that have not offshored production activities in the years 1999-2006. The propensity score is generated from regression IV in Table 4-1. ${ }^{* * *},\left({ }^{* *},{ }^{*}\right)$ indicates significance at the $1 \%,(5 \%, 10 \%)$ level of significance.

\subsection{Offshoring and product innovation}

This section is devoted to the analysis of Hypothesis 2, which claims that offshoring exerts a positive effect on subsequent product innovation. We measure product innovation by four variables: a dummy variable which is one if the firm has introduced a new product to the market between 2006 and 2009; a dummy variable which is one if the firm has introduced a market novelty between 2006 and 2009; the share of new products and market novelties on turnover in the year 2008. 
The data reveal that about $76 \%$ of the offshoring firms introduced new products, whereas about $62 \%$ of the matched non-offshoring firms, which proxy the counterfactual to the offshoring, report the introduction of new products. The significant effect $(p=0.000)$ of offshoring amounts to about $14 \%$ (see Table 4-5, first two rows).

In contrast to the increased likelihood of introducing new products the offshoring firms do not realize a higher economic relevance of product innovation. Products that are new to the firm generate about $17 \%$ of sales in offshoring firms. The matched non-offshoring firms generate a share of $16 \%$ by sales of new products. The difference is not significant at any conventional level of significance (see Table 4-5, third and fourth row). This finding suggests that, although offshoring firms have the capability to develop and introduce new products more frequently, they are not able to generate a higher fraction of sales through these products when compared with their matched non-offshoring firms.

Analogous to the interpretation of the findings in Table 4-5 the effect of offshoring on the introduction of market novelties - that is products that are new to the market - is positive and significant. We find that $59 \%$ of the offshoring firms introduce market novelties, whereas about $52 \%$ of the matched non-offshoring firms report the introduction of new products. The latter approximate the counterfactual to the treatment of offshoring. The significant effect $(p=0.050)$ of offshoring amounts to about $7 \%$ (see Table $4-5$, fifth and sixth row).

Table 4-5 Effect of offshoring on product innovation

\begin{tabular}{|c|c|c|c|c|c|}
\hline & & Obs & Mean & Std. Err. & Pr \\
\hline \multirow{2}{*}{ New products } & Offshoring (TG) & 352 & $0.760^{\star * *}$ & 0.023 & 0.000 \\
\hline & No Offshoring (CG) & 352 & 0.621 & 0.016 & \\
\hline \multirow{2}{*}{$\begin{array}{r}\text { Share of new products } \\
\text { on turnover }\end{array}$} & Offshoring (TG) & 230 & 16.900 & 1.091 & 0.463 \\
\hline & No Offshoring (CG) & 230 & 15.990 & 0.064 & \\
\hline \multirow{2}{*}{ Market novelties } & Offshoring (TG) & 247 & $0.587^{\star}$ & 0.031 & 0.050 \\
\hline & No Offshoring (CG) & 247 & 0.517 & 0.021 & \\
\hline \multirow{2}{*}{$\begin{array}{l}\text { Share of market } \\
\text { novelties on turnover }\end{array}$} & Offshoring (TG) & 113 & 9.000 & 1.016 & 0.767 \\
\hline & No Offshoring (CG) & 113 & 9.342 & 0.674 & \\
\hline \multirow{2}{*}{$\begin{array}{r}\text { Product development } \\
\text { time }\end{array}$} & Offshoring (TG) & 238 & 18.878 & 0.925 & 0.775 \\
\hline & No Offshoring (CG) & 238 & 18.567 & 0.676 & \\
\hline
\end{tabular}

Note: The group labelled as ,no offshoring' are all the companies in the sample that have not offshored production activities in the years 1999-2006. The propensity score is generated from regression IV in Table 4-1. ${ }^{* * *},\left({ }^{* *},{ }^{*}\right)$ indicates significance at the $1 \%,(5 \%, 10 \%)$ level of significance.

Here again, analogous to the findings for the economic relevance of new products (see Table 4-5, fifth and sixth row) firms do not realize a higher economic relevance from market 
novelties. This is documented in Table 4-5. Market novelties generate $9 \%$ of the sales of offshoring firms. The matched non-offshoring firms generate a share of about $9.3 \%$ by sales of market novelties. The difference is not significant at any conventional level of significance. This finding suggests that, although offshoring firms have the capability to conceptualize, develop and commercialize market novelties on a higher frequency, they cannot generate a higher fraction of sales through these products when compared with their matched non-offshoring companies.

Additionally we analyse whether the development time of new products is affected by offshoring of production activities. It has to be stressed here that the information contained in the offshoring indicator merely refers to production activities. It does not cover research, technology and innovation activities in a broad sense. As the latter activities tend not to follow production offshoring activities, at least not as long as national specification and adaptation for international markets do not require development activities. Hence, offshoring of production activities does affect the development process as such. This line of argument is supported by the findings in the last two rows of Table 4-5, where no significant difference in the development time between offshoring firms and the matched non-offshoring firms can be detected.

To sum up, offshoring generates a significant effect on probability to introduce new products - on the rejuvenation of the firms' product portfolio. It obviously does not, however, exert a positive effect on the generation of sales by these new products. Overall we find support for Hypothesis 2 when we consider the introduction of new products, regardless of their degree of novelty. We cannot reject the null-hypothesis corresponding to Hypothesis 2 when we consider the economic relevance of new products to be the appropriate measure of innovation output.

When digesting the findings obtained so far, we are tempted to conjecture that offshoring of production activities tends to increase the share of employees related to research, development, and design. This shift in the focus of the firms' activities leads to an increased innovation output measured by the firms' likelihood to introduce new products. These findings hold regardless of the degree of novelty of the product innovation.

The increased likelihood of introducing new products is not generated by a faster development process, as we find no effect on the development process. From this, one could conclude that the increased focus on innovation activities as exemplified by the increased innovation input, causes the increase in innovativeness. Yet, the increased innovation input induced by offshoring activities does not translate into the increased innovative sales. 


\subsection{Offshoring and process innovation}

Finally, we look at process innovation. Here we utilize a unique feature of the EMS data set: EMS supplies in-depth information about the respondent firm's utilization of various production technologies (see Table 3-4). This data allows us to investigate in detail Hypothesis 3 which focuses on the effect of offshoring on process innovation.

In chapter 3.1 we described how we constructed three indexes of involvement in specific fields of production technology and one index for overall technology involvement. Table 4-6 reports average values for each of the three technology involvement indexes and the overall index by sector. Please note that the indices of automation technologies, production technologies and digital factory technologies sum to the overall technology involvement index.

Table 4-6 Average process technology involvement by sector

\begin{tabular}{lllll}
\hline & \multicolumn{5}{c}{ Involvement in } \\
Sector (NACE Rev. 1.1) & All & Automation & Production & Digital factory \\
\hline Food products and beverages, tobacco & 1.155 & 0.713 & 0.123 & 0.319 \\
Textiles, clothing and leather & 1.422 & 0.668 & 0.402 & 0.352 \\
Wood and wood products & 1.437 & 0.741 & 0.334 & 0.362 \\
Pulp, paper and paper prod. & 1.550 & 0.841 & 0.299 & 0.410 \\
Publishing, printing recorded media & 1.409 & 0.696 & 0.254 & 0.459 \\
Coke, petroleum, chemical products & 1.668 & 0.812 & 0.356 & 0.500 \\
Rubber and plastic products & 2.112 & 1.007 & 0.530 & 0.575 \\
Other non-metallic mineral products & 1.506 & 0.847 & 0.335 & 0.324 \\
Basic metals & 2.301 & 1.110 & 0.514 & 0.677 \\
Fabricated metal products & 2.056 & 0.918 & 0.568 & 0.571 \\
Machinery and equipment n.e.c. & 2.012 & 0.859 & 0.543 & 0.610 \\
Office equ., electrical machinery and apparatus & 2.165 & 1.033 & 0.524 & 0.607 \\
Radio, television and communication equipment & 2.480 & 1.232 & 0.585 & 0.663 \\
Medical, precision and optical equipment & 2.115 & 0.916 & 0.600 & 0.599 \\
Motor vehicles and other transport equipment & 2.478 & 1.157 & 0.617 & 0.705 \\
Furniture; manufacturing n.e.c. & 1.867 & 0.831 & 0.469 & 0.567 \\
\hline Total & 1.889 & 0.889 & 0.467 & 0.534 \\
\hline Sourechologies & technologies \\
\hline
\end{tabular}

Source: EMS 
Overall we observe the strongest technology involvement among the manufacturers of radio, television and communication equipment, of motor vehicles and other transport equipment and among the manufacturers of basic metals. The sector showing the strongest involvement in automation technology is manufacturing of communication equipment. The sector with the highest involvement in production technologies and with the strongest involvement in digital factory technologies is manufacturing of motor vehicles.

The effect of offshoring on the overall technology involvement and the three subcategories is reported in Table 4-7. First, when comparing the overall technology involvement of offshoring companies in the first row of Table 4-7 (2.483) with the overall technology involvement of all companies in the sample in Table 4-6 (1.889) we observe that offshoring firms show a distinctively higher involvement, which indicates that they invest more in process innovation. Even after the matching, which accounts for the fact that offshoring is not a random event but affected by certain firm specific characteristics that in turn also affect the utilization of technologies, we observe a significant $(p=0.003)$ difference in the involvement of all technologies. As those matched non-offshoring firms are considered a proxy for the counterfactual to offshoring, the effect of offshoring on the overall technological utilization of advanced technologies in the production process is significant and positive. Thus, offshoring firms show a stronger involvement in advanced technologies in the production process than they would have in the counterfactual situation of being a non-offshoring firm.

As noted above the overall technological involvement is the aggregate index of three involvement indices covering more detailed sub-groups of advanced technologies in the production process. Investigating the effects on these sub-indices can reveal from which technologies this significant overall effect originates.

Let us first investigate the effect of offshoring on the utilization of automation technologies. This group of technologies comprises for instance seamless integration of digital product design / engineering with machine programming (CAD/CAM), industrial robots / handling systems in manufacturing and assembly, (process-)integrated quality control (e.g. by laser, ultrasonic waves, machine vision systems), radio frequency identification (RFID) utilization in on-site/external logistics, and automated warehouse management systems (WHS) for on-site logistics and order-picking. Most of these technologies have considerable potential for labour-savings in particular with respect to materials handling, storage, and quality control. According to EMS results, the main reason for their introduction is to increase productivity.

The results on the effect of offshoring on the involvement in automation technologies can be found in the third and fourth row of Table 4-7. Despite the labour-saving character of many of these technologies, we find that offshoring is associated with a subsequently higher involvement in automation technologies. The difference between 1.179 of the offshoring companies and 0.970 of the matched not-offshoring companies is highly significant $(p=0.000)$. Hence, offshoring is not a strategy to substitute capital-intensive process 
technologies in the home country by investments in low-wage countries. However, offshorers invest more in technologies to increase productivity at home than non-offshorers.

The sub-group of production technologies include laser as a tool (e.g. cutting, welding, forming, micro-structuring), dry processing/minimum quantity lubrication system, rapid prototyping or tooling (e. g. laser sintering, stereo lithography, 3D printing processes), application of bio- and gene-technology in manufacturing processes (e.g. catalysts, bio reactors), and processing of novel materials (e.g. composite materials, renewable raw materials). These technologies can increase productivity, but also contribute to innovation, for example if new materials allow new product propensities.

The fifth and sixth row of Table 4-7 summarizes the findings for the involvement in production technologies. For production technologies, the difference between the offshoring companies' involvement (0.611) and the matched non-offshoring companies (0.584) is not significant. We cannot reject the corresponding null-hypothesis about no effect of offshoring and conclude that offshoring does not affect the implementation of production technologies.

Table 4-7 Effect of offshoring on process innovation

\begin{tabular}{|c|c|c|c|c|c|}
\hline & & Obs & Mean & Std. Err. & $\operatorname{Pr}$ \\
\hline \multirow{2}{*}{$\begin{array}{l}\text { Overall involvement in } \\
\text { process technologies }\end{array}$} & Offshoring (TG) & 353 & $2.483^{\star \star \star}$ & 0.097 & 0.003 \\
\hline & No Offshoring (CG) & 353 & 2.156 & 0.062 & \\
\hline \multirow{2}{*}{$\begin{array}{r}\text { Automation } \\
\text { technologies }\end{array}$} & Offshoring (TG) & 353 & $1.179^{* * *}$ & 0.050 & 0.000 \\
\hline & No Offshoring (CG) & 353 & 0.970 & 0.029 & \\
\hline \multirow{2}{*}{$\begin{array}{r}\text { Production } \\
\text { technologies }\end{array}$} & Offshoring (TG) & 353 & 0.611 & 0.040 & 0.563 \\
\hline & No Offshoring (CG) & 353 & 0.584 & 0.028 & \\
\hline \multirow{2}{*}{ Digital technologies } & Offshoring (TG) & 353 & $0.692^{\star *}$ & 0.036 & 0.019 \\
\hline & No Offshoring (CG) & 353 & 0.602 & 0.021 & \\
\hline
\end{tabular}

Note: The group labelled as 'no offshoring' are all the companies in the sample that have not offshored production activities in the years 1999-2006. The propensity score is generated from regression IV in Table 4-1. ${ }^{* * *},\left({ }^{* *},{ }^{*}\right)$ indicates significance at the $1 \%,(5 \%, 10 \%)$ level of significance.

Digital factory technologies comprise digital exchange of operation scheduling data with supply chain management systems of suppliers/customers, manufacturing execution system (MES) (i.e. integration of PPS/ERP with production data logging, CAM), and virtual reality and/or simulation in product development and/or manufacturing. These technologies can increase the flexibility of the production process and help to link foreign and domestic production activities. Moreover, they also provide new tools for product development and therefore contribute to product innovation. 
The results indicate a significant difference $(p=0.019)$ between offshoring and nonoffshoring firms (last two rows of Table 4-7). The offshoring firms show an involvement index of 0.692 , whereas the non-offshoring companies, as the counterfactual, show an involvement of 0.602 . We interpret this as a sign that offshoring firms invest more in technologies to manage the value chain and promote international integration of production activities.

To sum up, offshoring of production activities is associated with more subsequent process innovation measured by a higher involvement in advanced technologies in the production process. This overall effect originates from a positive effect on automation technologies and on digital factory technologies. This is in line with the international economics literature which predicts that offshoring firms in the home country will focus on skill-intensive and capital-intensive activities. Offshoring of production activities therefore does not negatively affect the implementation of production technologies and industrial modernisation. 


\section{$5 \quad$ Results for Austria}

The previous chapter has revealed that offshoring firms specialize towards research, development, and design in their home countries and invest more in process innovation than non-offshoring firms than non-offshoring firms. This finding was based on a large sample of firms from seven countries. We used propensity score matching to compare offshoring and non-offshoring firms which share the same firm characteristics.

This chapter goes one step further and focuses on Austria. We will repeat the analysis of the previous chapter with a sample that only includes Austrian offshoring firms and their Austrian counterfactual. This approach shrinks the sample considerably; there are 50 Austrian offshoring firms in the sample. Unfortunately, it was not possible to find counterfactuals for 15 firms, which results in a sample size of only 35 firms, a considerable limitation for statistical analysis. We will therefore only report means and their standard deviations and no values for T-tests.

\subsection{Offshoring and the firms' production and value chain}

The results of chapter 4 showed that offshoring firms are more intensively embedded in international value chains. We can confirm this result for the sample of Austrian firms. Both, the share of exports and the share of imported intermediaries is higher for offshoring firms. Differences in the share of employees in production are only small and in favour of offshoring firms.

Table 5-1 Effects of offshoring on production activities and the value chain of Austrian firms

\begin{tabular}{llrrrrr}
\hline & & Obs & Mean & Std. Err. & Min. & Max. \\
\hline Share of employees in production & Offshoring (TG) & 35 & 60.8 & 18.0 & 5 & 90 \\
\cline { 2 - 7 } & No Offshoring (CG) & 35 & 59.2 & 14.6 & 17 & 90 \\
\hline Share of imported intermediates & Offshoring (TG) & 32 & 53.1 & 31.6 & 5 & 100 \\
\cline { 2 - 7 } & No Offshoring (CG) & 32 & 35.6 & 17.6 & 0 & 70 \\
\hline Share of exports on turnover & Offshoring (TG) & 32 & 63.1 & 35.1 & 0 & 100 \\
\cline { 2 - 6 } & No Offshoring (CG) & 32 & 52.5 & 22.6 & 11 & 99 \\
\hline Delivery time & Offshoring (TG) & 34 & 47.9 & 55.2 & 1 & 270 \\
\cline { 2 - 6 } & No Offshoring (CG) & 34 & 52.1 & 54.9 & 3 & 252 \\
\hline
\end{tabular}

Note: The group labelled as 'no offshoring' are all the companies in the sample that have not offshored production activities in the years 1999-2006. The propensity score is generated from regression IV in Table 4-1. 


\subsection{Offshoring and product innovation}

The clear advantages of offshoring firms in terms of innovation input we observed in the previous chapter cannot be found for Austrian firms (Table 5-2). Offshoring firms employ less R\&D personnel relative to total staff compared to non-offshoring firms, but a higher share of employees in design. The combined share for R\&D and design personnel is similar for offshoring and non-offshoring firms. This confirms the result of the previous chapter insofar as we see no negative effect from offshoring on innovation input. Moreover, the observation that the share of personnel working in design is higher in offshoring firms is also confirmed for Austria.

Table 5-2 Effects of offshoring on innovation input of Austrian firms

\begin{tabular}{lllllll}
\hline & Obs & Mean & Std. Err. & Min. & Max. \\
\hline $\begin{array}{r}\text { Share of personnel in R\&D } \\
\text { and design }\end{array}$ & Offshoring (TG) & 35 & 12.06 & 10.19 & 0 & 50 \\
\cline { 2 - 7 } & No Offshoring (CG) & 35 & 12.36 & 7.53 & 0 & 40 \\
\hline \multirow{3}{*}{\begin{tabular}{l} 
Share of personnel in R\&D \\
\cline { 2 - 7 }
\end{tabular}} & Offshoring (TG) & 35 & 3.89 & 5.85 & 0 & 30 \\
\hline \multirow{2}{*}{\begin{tabular}{l} 
Share of personnel in design Offshoring (CG) \\
\cline { 2 - 7 }
\end{tabular}} & 35 & 5.10 & 3.84 & 0 & 20 \\
\cline { 2 - 7 } & Offshoring (TG) & 35 & 8.17 & 7.17 & 0 & 30 \\
\cline { 2 - 7 } & No Offshoring (CG) & 35 & 7.26 & 4.36 & 0 & 20
\end{tabular}

Note: The group labelled as 'no offshoring' are all the companies in the sample that have not offshored production activities in the years 1999-2006. The propensity score is generated from regression IV in Table 4-1.

\subsection{Offshoring and product innovation}

One of the most striking results of the previous chapter is the finding that offshoring firms more successfully introduce new products to the market, but are not able to reap higher rewards in terms of turnover from new products and market novelties.

The analysis for the Austrian sample partly confirms this result (Table 5-3). The share of offshoring firms which introduced products new to the firm is higher than the corresponding share for non-offshoring firms. However, the share of offshoring firms with market novelties is lower. Results for the turnover shares are in line with the results for the whole sample, but suffer considerably from the low number of observations. 


\begin{tabular}{llrrrrr}
\hline \multirow{2}{*}{ New products } & Obs & Mean & Std. Err. & Min. & Max. \\
\hline & Offshoring (TG) & 35 & 0.69 & 0.47 & 0 & 1 \\
\cline { 2 - 7 } & No Offshoring (CG) & 35 & 0.62 & 0.33 & 0 & 1 \\
\hline Share of new products on turnover & Offshoring (TG) & 20 & 15.85 & 9.71 & 0 & 37 \\
\cline { 2 - 7 } & No Offshoring (CG) & 20 & 13.88 & 6.01 & 1.57 & 25 \\
\hline Market novelties & Offshoring (TG) & 21 & 0.43 & 0.51 & 0 & 1 \\
\cline { 2 - 7 } & No Offshoring (CG) & 21 & 0.52 & 0.39 & 0 & 1 \\
\hline Share of market novelties on & Offshoring (TG) & 8 & 9.00 & 9.74 & 0 & 30 \\
\cline { 2 - 7 } turnover & No Offshoring (CG) & 8 & 6.52 & 3.23 & 1.75 & 10.06 \\
\hline Product development time & Offshoring (TG) & 20 & 14.15 & 7.76 & 5 & 36 \\
\cline { 2 - 7 } & No Offshoring (CG) & 20 & 20.17 & 11.39 & 6 & 60 \\
\hline
\end{tabular}

Note: The group labelled as 'no offshoring' are all the companies in the sample that have not offshored production activities in the years 1999-2006. The propensity score is generated from regression IV in Table 4-1.

\subsection{Offshoring and process innovation}

Finally, we look at process innovation. The dataset allows a very detailed examination of firm investments in various process technologies, as well as an assessment of the overall propensity of the firm to invest in process innovation.

Contrary to the results for the full sample, Austrian non-offshoring firms seem to invest more intensively in advanced process technologies than their offshoring counterparts (Table 5-4). The value for overall involvement index in process technologies is 2.53 for non-offshoring firms compared to a value of 2.28 for offshoring firms. Similar differences in favour of nonoffshoring firms can be observed for production and digital technologies.

The sample is too small to provide measures for the significance of these differences. However, the fact that three of the four indicators are lower for non-offshoring firms than for offshoring firms is a hint that the difference is not zero.

How can this deviation of Austrian firms from the European trend be explained? We believe the reason lies in the focus of Austrian active FDI on Central- and Eastern-European countries. These locations are proximate to Austria, but offer considerable lower wage costs compared to Austria, which may give lower incentives for process innovation at home compared to other countries with more active FDI in high-wage locations or in geographically distant locations in Asia. 


\begin{tabular}{llrrrrr}
\hline & & Obs & Mean & Std. Err. & Min. & Max. \\
\hline Overall involvement in process & Offshoring (TG) & 35 & 2.28 & 1.63 & 0 & 7.60 \\
technologies & No Offshoring (CG) & 35 & 2.53 & 1.24 & 0.12 & 6.00 \\
\hline Automation technologies & Offshoring (TG) & 35 & 1.08 & 0.95 & 0 & 3.77 \\
\cline { 2 - 8 } & No Offshoring (CG) & 35 & 1.08 & 0.63 & 0.12 & 2.91 \\
\hline Production technologies & Offshoring (TG) & 35 & 0.52 & 0.64 & 0 & 2.47 \\
\cline { 2 - 8 } & No Offshoring (CG) & 35 & 0.67 & 0.63 & 0 & 2.68 \\
\hline Digital technologies & Offshoring (TG) & 35 & 0.69 & 0.68 & 0 & 2.23 \\
\cline { 2 - 7 } & No Offshoring (CG) & 35 & 0.78 & 0.51 & 0 & 2.00
\end{tabular}

Note: The group labelled as 'no offshoring' are all the companies in the sample that have not offshored production activities in the years 1999-2006. The propensity score is generated from regression IV in Table 4-1.

We conclude that the analysis of a sub-sample with Austrian firms confirms some, but not all findings from the analysis of the large sample. In particular, we find $\mathrm{H} 2$ and $\mathrm{H} 1$ partly confirmed by the data. $\mathrm{H} 3$ is not supported by the observations of Austrian firms. The size of the sample, however, does not allow to show that the differences observed between offshoring and non-offshoring firms are significant. 


\section{Conclusions and policy issues}

The consequences of FDI and production offshoring for the home countries are a muchdiscussed topic in economic policy. This study investigates the effects of offshoring on R\&D, product and process innovation of firms in the home country. Innovation capabilities resulting from systematic $R \& D$, the implementation of advanced production technologies and the subsequent innovation performance are the key element of long-term competitiveness of Western economies.

Overall, we see no negative effect of production offshoring on innovation and technological capabilities of firms in the home country. On contrary, offshoring induces firms to specialize in their home countries towards research, development, and design and to invest in process innovation. This result also partly holds true in an analysis of a sub-simple which only consists of Austrian firms. Here, however, results suffer from a low number of observation.

The effects on innovation input, including R\&D and design, are univocally positive. Offshoring of production activities is associated with a significant higher input in R\&D and non-R\&D innovation activities.

The analysis of product innovation give a more differentiated picture of the effects of offshoring: production offshoring is associated with a higher likelihood of product innovation, regardless of the degree of novelty of the product innovation. However, product innovation does not show any relationship with the share of sales from new products. Yet, it can be argued that this particular indicator rather captures the product lifecycle in the firm, than the firm specific relevance of product innovation. Our findings can hence also be interpreted that offshoring does not affect the lifecycle of the product of the offshoring firm.

Finally, the analysis reveals a positive effect of production offshoring on process innovation. Firms which offshored production activities invest more in advanced production technologies. The difference between offshoring and non-offshoring firms can be explained by stronger investment in automation technologies and in digital factory technologies.

A discussion of the results of this study has to consider the global financial crisis, which has reached its climax during the observation period 2007-Mid 2009. Although we cannot provide a comparison of innovation behaviour of offshoring and non-offshoring firms before and during the crisis, there is reason to believe that offshoring firms reduced their innovation activities stronger during the crisis than non-offshoring firms. Empirical evidence suggests that export-oriented firms were more severely hit by the crisis and exhibited more severe cuts in innovation and R\&D expenditure than less export-oriented firms (Paunov 2012; Rammer 2012; Archibugi et al. 2013). We have shown that offshoring firms are much stronger embedded in international value chains than non-offshoring firms. Thus, we can assume that the crisis has narrowed down the differences between offshoring and nonoffshoring firms observed in the preceding chapters. 
The results carry some implications for international economics as well as for economic policy. Our findings add empirical evidence on this complementarities between offshoring and innovation, a field where empirical results were scarce so far (Barba Navaretti and Falzoni 2004; Olsen 2006). We present evidence for positive home-country effects for technological upgrading, in particular process innovation. The results support a view on internationalisation of firms that regards offshoring as an strategy of international expansion, and not a passive reaction of firms to a loss of their competitiveness. We show that this expansion goes hand in hand with innovation and process modernization at home. This view is in line with the international business literature (Dunning 2001; Dunning and Lundan 2008) and the international economics literature (Helpman et al. 2004; Helpman 2006) where internationalisation is explained by the wish of the firm to exploit superior firmspecific assets at international markets.

With respect to policy, the analysis cannot confirm fears of a 'hollowing out' of national competitiveness from offshoring. The activities that add to the technological capabilities of firms and their ability to create competitive advantage - such as R\&D, design or process innovation - are positively associated with a firm's decision to relocate production activities to foreign countries. Thus, protective policy measures to prevent production offshoring do not seem to be a suitable approach to strengthen domestic technological capabilities and value-adding competences.

Second, our findings indicate complementarities between domestic education and innovation policies and internationalisation strategies of countries. Politics should be aware that domestic firms are likely to specialise in more knowledge-intensive activities when they internationalize their production activities. Consequently, policy can help to take full advantage of the benefits from internationalisation by promoting education and qualifying personnel early enough, particularly in countries or regions where talent is short.

Third, the results support a broad approach in science, technology and innovation policy that goes beyond the sole promotion of R\&D. Although we did not study the contribution of $R \& D$, design and different forms of process innovation to firm performance separately, it is obvious from the results that offshoring firms invest in all three forms of innovation. This may give reason to re-think the focus on R\&D which dominated Austrian science, technology and innovation policy over the last decade. 


\section{$7 \quad$ References}

Ambos, B., and B. B. Schlegelmilch (2006). Learning from foreign subsidiaries: An empirical investigation of headquarters' benefits from reverse knowledge transfers. International Business Review, 15(3): 294-312.

Amiti, M., and S.-J. Wei (2009). Service Offshoring and Productivity: Evidence from the US. World Economy, 32(2): 203-220.

Barba Navaretti, G., and A. M. Falzoni (2004). Home Country Effects of Foreign Direct Investment. In G. Barba Navaretti, \& A. J. Venables (eds.), Multinational Firms in the World Economy: 217-239. Princeton and Oxford: Princeton University Press.

Becker, S. O., K. Ekholm, and M.-A. Muendler (2012). Offshoring and the onshore composition of tasks and skills. Journal of International Economics, in press.

Bloom, N., and J. Van Reenen (2010). Why Do Management Practices Differ across Firms and Countries? Journal of Economic Perspectives, 24(1): 203-224.

Blundell, R., and M. Costa Dias (2000). Evaluation Methods for Non-Experimental Data. Fiscal Studies, 21(4): 427-468.

Bozeman, B., and M. Gaughan (2007). Impacts of grants and contracts on academic researchers' interactions with industry. Research Policy, 36(5): 694-707.

Bozeman, B., and M. Gaughan (2011). How do men and women differ in research collaborations? An analysis of the collaborative motives and strategies of academic researchers. Research Policy, 40(10): 1393-1402.

Braunerhjelm, P., and L. Oxelheim (2000). Does Foreign Direct Investment Replace Home Country Investment? The Effect of European Integration on the Location of Swedish Investment. Journal of Common Market Studies, 38(2): 199-221.

Cassiman, B., and R. Veugelers (2006). In Search of Complementarity in Innovation Strategy: Internal R\&D and External Knowledge Acquisition. Management Science, 52(1): 68-82.

Cohen, W. M. (1995). Empirical Studies of Innovative Activity. In P. Stoneman (ed.), Handbook of Innovation and Technological Change: 182-264. Oxford: Blackwell.

Cohen, W. M. (2010). Fifty Years of Empirical Studies of Innovative Activity and Performance. In B. A. Hall, \& N. Rosenberg (eds.), Handbook of Economics of Innovation: 129-213. Amsterdam: Elsevier.

Crinò, R. (2009). Offshoring, Multinationals and Labor Market: A Review of the Empirical Literature. Journal of Economic Surveys, 23(2): 197-249.

Crinò, R. (2012). Imported inputs and skill upgrading. Labour Economics, 19(6): 957-969.

Czarnitzki, D. (2005). The Extent and Evolution of Productivity Deficiency in Eastern Germany. Journal of Productivity Analysis, 24: 211-231. 
D'Agostino, L. M., K. Laursen, and S. Massini (2010). The Impact of R\&D Offshoring on the Home Knowledge Production of OECD Investing Regions Copenhagen: DRUID Working Paper No. 10-19.

D’Agostino, L. M., K. Laursen, and G. D. Santangelo (2013). The impact of R\&D offshoring on the home knowledge production of OECD investing regions. Journal of Economic Geography, 13(1): 145-175.

Dachs, B., M. Borowiecki, S. Kinkel, and T. C. Schmall (2012). The Offshoring of Production Activities in European Manufacturing. MPRA Paper Nr 42973.

Dell'mour, R. (2012). Direktinvestitionen 2010. Österreichische Direktinvestitionen im Ausland und ausländische Direktinvestitionen in Österreich. Wien: Oesterreichische Nationalbank.

Desai, M. A., F. C. Foley, and J. R. J. Hines (2009). Domestic Effects of the Foreign Activities of US Multinationals. American Economic Journal: Economic Policy, 1(1): 181203.

Dosi, G. (1982). Technological Paradigms and Technological Trajectories: A Suggested Interpretation of the Determinants and Directions of Technical Change. Research Policy, 11(3): 147-162.

Dosi, G. (1988). Sources, Procedures, and Microeconomic Effects of Innovation. Journal of Economic Literature, 26(3): 1120-1171.

Dunning, J., and S. M. Lundan (2008). Multinational Enterprises and the Global Economy (2nd ed.). Cheltenham: Edward Elgar.

Dunning, J. H. (2001). The Eclectic (OLI) Paradigm of International Production: Past, Present and Future. International Journal of the Economics of Business, 8(2): 173-190.

Ebersberger, B., and S. J. Herstad (2011). Product Innovation and the Complementarities of External Interfaces. European Management Review, 8(3): 117-135.

Ebersberger, B., and S. J. Herstad (2012). The relationship between international innovation collaboration, intramural R\&D and SMEs' innovation performance: A quantile regression approach. Applied Economic Letters, forthcoming.

Egger, H., and P. Egger (2003). Outsourcing and skill-specific employment in a small economy: Austria after the fall of the Iron Curtain. Oxford Economic Papers, 55: Pp. 625643.

Egger, P., and M. Pfaffermayr (2009). Multinationals Have Higher Domestic Investments Than National Firms. Leverhulme Centre for Research on Globalisation and Economic Policy (GEP), University of Nottingham.

Falk, M., and Y. Wolfmayr (2010). The Extent, Characteristics and Impacts of FDI and Multinational Firm Activities. A Firm Level Analysis. Vienna: FIW Research Reports Nº 06.

Fariñas, J. C., and A. Martín-Marcos (2010). Foreign Sourcing and Productivity: Evidence at the Firm Level. World Economy, 33(3): 482-506. 
Feldstein, M. S. (1994). The Effects of Outbound Foreign Direct Investment on the Domestic Capital Stock, NBER Working Paper, Vol. 4668.

Fors, G. (1997). Utilization of R\&D Results in the Home and Foreign Plants of Multinationals. Journal of Industrial Economics, 45(3): 341-358.

Fritsch, M., and V. Slavtchev (2010). How does industry specialization affect the efficiency of regional innovation systems? The Annals of Regional Science, 45(1): 87-108.

Gaughan, M., and E. A. Corley (2010). Science faculty at US research universities: The impacts of university research center-affiliation and gender on industrial activities. Technovation, 30(3): 215-222.

Hansson, P. (2005). Skill upgrading and production transfer within Swedish multinationals. Scandinavian Journal of Economics, 107(4): 673-692.

Harrison, A., and M. McMillan (2010). Offshoring Jobs? Multinationals and U.S. Manufacturing Employment. Review of Economics and Statistics, 93(3): 857-875.

Head, K., and J. Ries (2002). Offshore Production and Skill Upgrading by Japanese Manufacturing Firms. Journal of International Economics, 58: 81-105.

Head, K., and J. Ries (2003). Heterogeneity and the FDI versus Export Decision of Japanese Manufacturers, NBER Working Paper, Vol. 10052.

Heckman, J. J., H. Ichimura, and J. Smith (1998). Matching as an econometric evaluation estimator. Review of Economic Studies, 65(2): 261-294.

Helpman, E. (2006). Trade, FDI and the Organisation of Firms. Journal of Economic Literature, XLIV(3): 589-631.

Helpman, E., M. J. Melitz, and S. R. Yeaple (2004). Export Versus FDI with Heterogeneous Firms. American Economic Review, 94(1): 300-316.

Jabbour, L. (2010). Offshoring and Firm Performance: Evidence from French Manufacturing Industry. World Economy, 33(3): 507-524.

Karpaty, P., and P. G. Tingvall (2011). Offshoring and Home Country R\&D. Stockholm: CESIS Working Paper No. 254.

Ketokivi, M., and J. Ali-Yrkkö (2009). Unbundling R\&D and Manufacturing: Postindustrial Myth or Economic Reality? Review of Policy Research, 26(1-2): 35-54.

Kline, S., and N. Rosenberg (1986). An Overview of Innovation. In R. Landau, \& N. Rosenberg (eds.), The Positive Sum Strategy - Harnessing Technology for Economic Growth: 275-305. Washington: National Academy Press.

Laursen, K., F. Masciarelli, and A. Prencipe (2012). Regions Matter: How Localized Social Capital Affects Innovation and External Knowledge Acquisition. Organization Science, 23(1): 177-193.

Laursen, K., and A. Salter (2006). Open for Innovation: The Role of Openness in Explaining Innovation Performance among UK Manufacturing Firms. Strategic Management Journal, 27: 131-150. 
Lipsey, R. E. (2002). Home and Host Country Effects of FDI, NBER Working Paper, Vol. 9293. Cambridge, MA.

Morrison Paul, C. J., and M. Yasar (2009). Outsourcing, productivity, and input composition at the plant level. Canadian Journal of Economics, 42(2): 422-439.

Muscio, A. (2006). Patterns of Innovation in Industrial Districts: An Empirical Analysis. Industry and Innovation, 13(3): 291-312.

Narula, R., and J. Michel (2009). Reverse knowledge transfer and its implications for European policy. Maastricht: UNU-MERIT Working Paper.

Neureiter, M., and P. Nunnenkamp (2010). Outsourcing Motives, Location Choice and Labour Market Implications: An Empirical Analysis for European Countries. Kyklos, 63(2): 206-230.

Nieto, M. J., and L. Santamaría (2007). The importance of diverse collaborative networks for the novelty of product innovation. Technovation, 27(6-7): 367-377.

OECD (2005). Oslo Manual. Guidelines for Collecting and Interpreting Innovation Data (3rd ed.). Paris: Organisation for Economic Co-operation and Development.

OECD (2013). FDI in Figures. Paris: Organisation for Economic Co-operation and Development. http://www.oecd.org/daf/inv/FDI\%20in\%20figures.pdf

Olsen, K. B. (2006). Productivity Impacts of Offshoring and Outsourcing: A Review. Paris: OECD STI Working Paper 2006/1.

Patel, P., and K. Pavitt (1997). The Technological Competencies of the Wold's Largest

Firms: Complex and Path-Dependent, But Not Much Variety. Research Policy, 26: 141-156.

Pavitt, K. (2005). Innovation Processes. In J. Fagerberg, D. C. Movery, \& R. R. Nelson (eds.), The Oxford Handbook of Innovation: 86-114. Oxford: Oxford University Press.

Piscitello, L., and L. Rabbiosi (2006). How does Knowledge Transfer from Foreign Subsidiaries affect Parent Companies' Innovative Capacity? Copenhagen:

Rosenbaum, P. R., and D. B. Rubin (1983). The central role of the propensity score in observational studies for causal effects. Biometrika, 70: 41-55.

Rosenberg, N. (1990). Why Do Firms Do Basic Research (With Their Own Money)? Research Policy, 9(2): 165-174.

Rothwell, R. (1992). Successful industrial innovation: critical factors for the 1990s. $R \& D$ Management, 22(3): 221-240.

Schmiedeberg, C. (2008). Complementarities of innovation activities: An empirical analysis of the German manufacturing sector. Research Policy, 37(9): 1492-1503.

Simpson, H. (2012a). How do Firms' Outward FDI Strategies Relate to their Activity at Home? Empirical Evidence for the UK. The World Economy, 35(3): 243-272.

Simpson, H. (2012b). Investment abroad and labour adjustment at home: evidence from UK multinational firms. Canadian Journal of Economics, 45(2): 698-731. 
Slaughter, M. J. (2000). Production transfer within multinational enterprises and American wages. Journal of International Economics, 50(2): 449-472.

Som, O. (2012). Innovation without R\&D: Heterogeneous Innovation Patterns of Non-R\&DPerforming Firms in the German Manufacturing Industry. Wiesbaden: Springer Gabler.

Stehrer, R., M. Borowiecki, B. Dachs, D. Hanzl-Weiss, S. Kinkel, J. Pöschl, M. Sass, T. C. Schmall, and A. Szalavetz (2012). Global value chains and the EU industry. Vienna: wiiw research reports no. 383 .

Tecu, I. (2011). The Location of Industrial Innovation: Does Manufacturing Matter? Brown University. 


\section{Appendix}

Table 9-1 Share of firms which have introduced a certain process technology

\begin{tabular}{|c|c|c|c|c|c|c|c|c|c|c|c|c|c|}
\hline \multirow[b]{2}{*}{ Sector (NACE Rev. 1.1) } & \multicolumn{13}{|c|}{ Technologies (see Table 3-4 for full labels of the technologies) } \\
\hline & CAD & $\mathrm{ROB}$ & QUC & RFID & WHS & LAS & DRY & RAP & GEN & MAT & SCM & MES & VIR \\
\hline $15-16$ & 0.06 & 0.20 & 0.22 & 0.05 & 0.19 & 0.02 & 0.02 & 0.00 & 0.02 & 0.04 & 0.24 & 0.13 & 0.02 \\
\hline $17-19$ & 0.18 & 0.01 & 0.06 & 0.01 & 0.13 & 0.05 & 0.06 & 0.01 & 0.00 & 0.22 & 0.20 & 0.14 & 0.04 \\
\hline 20 & 0.36 & 0.20 & 0.15 & 0.01 & 0.13 & 0.03 & 0.02 & 0.03 & 0.00 & 0.18 & 0.17 & 0.13 & 0.05 \\
\hline 21 & 0.15 & 0.21 & 0.29 & 0.11 & 0.19 & 0.04 & 0.02 & 0.02 & 0.00 & 0.13 & 0.35 & 0.22 & 0.05 \\
\hline 22 & 0.18 & 0.08 & 0.30 & 0.01 & 0.12 & 0.07 & 0.02 & 0.04 & 0.01 & 0.11 & 0.25 & 0.26 & 0.05 \\
\hline $23-24$ & 0.10 & 0.23 & 0.17 & 0.08 & 0.24 & 0.03 & 0.01 & 0.03 & 0.06 & 0.15 & 0.22 & 0.23 & 0.09 \\
\hline 25 & 0.31 & 0.34 & 0.31 & 0.05 & 0.15 & 0.07 & 0.04 & 0.10 & 0.01 & 0.26 & 0.36 & 0.33 & 0.11 \\
\hline 26 & 0.24 & 0.28 & 0.24 & 0.04 & 0.08 & 0.07 & 0.05 & 0.01 & 0.01 & 0.14 & 0.14 & 0.14 & 0.04 \\
\hline 27 & 0.41 & 0.32 & 0.48 & 0.08 & 0.17 & 0.15 & 0.23 & 0.07 & 0.01 & 0.05 & 0.34 & 0.43 & 0.19 \\
\hline 28 & 0.43 & 0.26 & 0.19 & 0.03 & 0.12 & 0.19 & 0.16 & 0.05 & 0.01 & 0.09 & 0.26 & 0.27 & 0.12 \\
\hline 29 & 0.42 & 0.19 & 0.13 & 0.03 & 0.19 & 0.16 & 0.12 & 0.08 & 0.01 & 0.10 & 0.29 & 0.25 & 0.18 \\
\hline $30-31$ & 0.31 & 0.18 & 0.27 & 0.08 & 0.19 & 0.18 & 0.07 & 0.09 & 0.00 & 0.09 & 0.37 & 0.29 & 0.13 \\
\hline 32 & 0.52 & 0.39 & 0.57 & 0.05 & 0.27 & 0.18 & 0.02 & 0.14 & 0.00 & 0.11 & 0.51 & 0.40 & 0.23 \\
\hline 33 & 0.43 & 0.23 & 0.29 & 0.03 & 0.16 & 0.20 & 0.07 & 0.17 & 0.00 & 0.14 & 0.29 & 0.26 & 0.20 \\
\hline $34-35$ & 0.40 & 0.36 & 0.38 & 0.09 & 0.25 & 0.11 & 0.18 & 0.07 & 0.00 & 0.23 & 0.44 & 0.31 & 0.29 \\
\hline 36 & 0.53 & 0.22 & 0.07 & 0.02 & 0.18 & 0.07 & 0.05 & 0.04 & 0.01 & 0.23 & 0.34 & 0.26 & 0.14 \\
\hline Total & 0.33 & 0.23 & 0.22 & 0.04 & 0.16 & 0.12 & 0.08 & 0.06 & 0.01 & 0.13 & 0.28 & 0.25 & 0.13 \\
\hline
\end{tabular}

See Table 3-2 for the full sector labels 